\title{
Is Preference for Global Brands in Emerging Markets Determined by "True" Globalness or "Mere" Foreignness?
}

\author{
Fernando Fastoso and Nina Reynolds
}

\begin{abstract}
The complementary literatures on perceived brand globalness and brand origin posit that consumers in emerging markets prefer nonlocal over local brands because they perceive such brands as being global and foreign, respectively. This study bridges these two literatures by disentangling the effects that perceptions of brand globalness and foreignness have on brand preference with consumers in emerging markets, i.e., consumers for whom most global brands are also foreign. Specifically, we present two alternative models of how perceived brand globalness and perceived brand foreignness interact to impact purchase likelihood. In model 1, perceived brand foreignness mediates the impact of perceived brand globalness on purchase likelihood. In model 2, perceived brand globalness and perceived brand foreignness impact purchase likelihood independently but through shared mediators. We use categorization theory to justify the expectation that consumers in emerging markets will prefer global brands because of their foreignness rather than their globalness.
\end{abstract}

\footnotetext{
F. Fastoso $(\bowtie)$

University of York, York, United Kingdom

e-mail: fernando.fastoso@york.ac.uk

N. Reynolds

University of Wollongong, Wollongong, NSW, Australia

e-mail: ninar@uow.edu.au
} 